\title{
Zacarias de Góes e Vasconcelos e seus discursos no Senado entre 1868 e 1869
}

Zacarias de Góes e Vasconcelos and his discussions in the senate between 1868 and 1869

\author{
Jaqueline Schmitt da Silva*
}

\author{
Palavras-chave: \\ Zacarias de Góes \\ Monarquia \\ Poder moderador
}

Keywords:

Zacarias de Góes

Monarchy

Power moderator

\begin{abstract}
Resumo: Neste trabalho, pretendemos abordar a crise de 1868 e a atuação de Zacarias de Góes e Vasconcelos através da análise do conteúdo de quatro discursos proferidos no Senado do Império entre 30 de junho de 1868 e 26 de junho de 1869. Tais discursos abordavam as disputas políticas entre os conservadores e a liga progressista, os debates acerca das atribuições do poder moderador, o senado vitalício e sua influência nas decisões, bem como "a causa e o modo" da sua exoneração em julho de 1868 e da queda do gabinete de 3 de agosto. A crise ministerial de 1868 abriu espaço para a exacerbação das críticas à ordem vigente, além de cisão dentro dos partidos Liberal e Conservador e a configuração de novos grupos que reivindicavam espaço para participação na política.
\end{abstract}

\begin{abstract}
In this work, we intend to address the crisis of 1868 and the work of Zacarias de Góes and Vasconcelos through the analysis of the content of four speeches given in the Senate of the Empire between june 30, 1868 and june 26, 1869. Such speeches dealt with political disputes between the Conservatives and the Progressive League, the debates over the attributions of moderating power, the Senate for life and its influence on decisions, as well as "the cause and mode" of its exoneration in july 1868 and the fall of the Cabinet of 3 august. The ministerial crisis of 1868 opened space for the exacerbation of criticism of the prevailing order, as well as a split within the Liberal and Conservative parties and the configuration of new groups that demanded space for participation in politics.
\end{abstract}

Recebido em $1^{\circ}$ de outubro de 2018. Aprovado em 21 de fevereiro de 2019.

\section{Introdução}

Cercado por repúblicas, em 1822, o Império do Brasil surgia como resultado da independência diante da colonização portuguesa na América. A vinda da corte portuguesa para o Brasil, em 1808, produziu modificações importantes e influenciou na construção de um sistema monárquico após a independência, bem como na unificação e relativa estabilidade, que se produziu no período logo após o desenlace colonial. A dominação portuguesa se fez de maneira distinta da dominação espanhola, o que acarretou um processo de construção diferente quanto ao sistema político a ser instaurado. Enquanto a região portuguesa formava um único país em 1825, a região correspondente aos espanhóis acabou convertida em 17 países independentes, em um processo que levou meio século (CARVALHO, 2013, p. 13-14). A opção pelo regime monárquico, a unidade territorial e a conformação de um governo estável são pontos que se devem ao fato de predominar na região da América portuguesa uma elite política particularizada, em especial, devido a uma homogeneidade ideológica e de treinamento. Originárias das classes dominantes, essa conformidade acabava por atenuar as disputas dentro da própria elite, ao mesmo tempo em que proporcionava um paradigma de dominação política (CARVALHO, 2013, p. 21).

\footnotetext{
* Bolsista Capes. Professora da Secretaria de Educação do Rio Grande do Sul. Mestra em História e Doutoranda em História pela Universidade de Passo Fundo (UPF). E-mail: <jaqueline.schmitt@hotmail.com>.
} 
Tal homogeneidade ideológica era construída a partir de uma formação acadêmica com origem comum. Juristas e magistrados que desempenharam papel fundamental na condução administrativa do regime colonial e após no Brasil independente, haviam tido formação em Direito na Universidade de Coimbra (fundada em 1290, com forte influência da tradição romana advinda de Bolonha e com tendência a justificar a vontade e supremacia dos reis diante da Igreja ou dos barões). A coesão de ideias proporcionada pela formação comum tornou a elite brasileira exitosa no processo de formação do Estado, uma vez que um contexto de ideias homogêneas configurava maior potencial de agir politicamente (CARVALHO, 2013, p. 34). Na primeira metade do Oitocentos, a elite brasileira teve formação em Coimbra. A maior parte se dedicou à formação jurídica e ocupou espaço entre os funcionários públicos, magistratura e exército (CARVALHO, 2013, p. 37).

Tal debate em torno da questão ideológica como mecanismo de conformação unificada do Estado brasileiro é apresentada por José Murilo de Carvalho. A coesão daquela elite diminuiu os conflitos internos e também as possibilidades de ascensão social, devido à inexistência de modificações abruptas nas estruturas do poder. Sem desconsiderar, também, a continuidade da escravidão, que limitou ainda mais a questão da mobilidade social. A burocracia estatal tornava-se a principal via de mobilidade.

Gerava-se, então, uma situação contraditória em que o Estado dependia, para sua manutenção, do apoio e das rendas geradas pela grande agricultura escravista de exportação, mas, ao mesmo tempo, tornavase refúgio para os elementos mais dinâmicos que não encontravam espaço de atuação dentro dessa agricultura. Instalava-se dentro do próprio Estado uma ambiguidade básica que dava à elite política certa margem de liberdade e ação. (CARVALHO, 2013, p. 40-41).

Naquele período, o emprego público era carreira de prestígio, que serviu para impulsionar a ascensão de muitos nordestinos pertencentes às famílias agrárias decadentes, a exemplo de Nabuco de Araújo. A burocracia, assim, dividia com a elite uma homogeneidade ideológica que provinha mais do treinamento, do que de uma condição social comum. Por outro lado, o Estado dependia da produção agrícola realizada em grandes fazendas escravistas, fator que delimitaria sua possibilidade de agir (CARVALHO, 2013, p. 42).

A feição comercial adotada pela colonização portuguesa na América, aliada ao aspecto do monopólio, constituem elementos primordiais de caracterização do Antigo Sistema Colonial. Para Ilmar Mattos, o monopólio era o componente essencial para a unificação das duas faces da moeda colonial: de um lado, a cara, equivalente ao Reino ou Estado Moderno; do outro lado, a coroa, a face colonial, a propriedade colonial, e, como resultado, os proprietários coloniais (MATTOS, 2011, p. 3132; p. 43). A vinda da família real romperia com o monopólio comercial, aspecto central do pacto colonial, ou como afirmou Mattos, quem rompeu com o pacto foram os próprios agentes da Coroa portuguesa, o que se fez necessário pela própria situação do sistema colonial mercantil (MATTOS, 2011, p. 44). A construção do Estado imperial estava conectada com a ascensão ao poder político de homens produtores de café, donos de terras e escravos na região sudeste. Tal fato se deu através de suas ligações com o Partido Conservador, os saquaremas. À vista disso, a construção do Estado imperial estava ligada à constituição de uma classe senhorial e à expansão desse grupo político, que procurava, entre outros, proteger os interesses escravistas. Mattos também aponta a educação como ponto importante na construção do Estado e também como artifício da classe senhorial, uma vez que proporcionou a uniformização da instrução pública (MATTOS, 2011, p. 287).

Nesse contexto de construção nacional, dois partidos se revezaram no poder: o Liberal e o Conservador. Faoro entendeu que o Partido Liberal estava mais próximo das grandes propriedades rurais, tendo em vista que a descentralização defendida pelos liberais seria positiva para tal grupo que ambicionava poder local. Os conservadores estariam mais próximos dos comerciantes e 
senhores de créditos que dominavam o meio agrário (FAORO, 2012, p. 389-390). Oliveira Torres afirmava que o Partido Conservador possuía bases rurais, e o Liberal, bases urbanas (TORRES, 1957, p. 337). José Murilo de Carvalho destacou que um Estado forte e centralizado era a principal defesa do Partido Conservador, do qual faziam parte proprietários de terras e escravos, dedicados à agricultura para exportação, principalmente nas regiões da Bahia, Rio de Janeiro e Pernambuco. Os liberais, favoráveis à descentralização, eram proprietários rurais voltados ao mercado interno, localizados em Minas Gerais, São Paulo e Rio Grande do Sul (CARVALHO, 2012, p. 95).

Ao longo do Segundo Reinado, os partidos Liberal e Conservador se revezaram no cenário político. Após o fracasso das revoltas liberais em 1842 , os conservadores chegaram ao poder com Honório Hermeto Carneiro Leão, o marquês de Paraná. Um ano depois, o gabinete foi demitido e os liberais foram convocados. $\mathrm{Na}$ ocasião, permaneceram no poder até 1848 . Nesse interim, as ações dos liberais eram projetos defendidos pelos conservadores, a exemplo da Tarifa Alves Branco, que elevou os impostos sobre produtos importados. Em 1847, foi criado o cargo de presidente do Conselho de Ministros. Em 1848, teve início o período denominado Conciliação, com a adesão dos dois partidos, na tentativa de construir estabilidade política. Sob a égide conservadora, a Conciliação foi organizada ao redor da chamada Trindade saquarema, constituída por políticos conservadores ortodoxos, principalmente Eusébio de Queirós, o visconde de Itaboraí e o visconde do Uruguai. O ano de 1856 pôs fim ao gabinete da conciliação, com a morte do líder marquês de Paraná, ocasião em que Caxias foi chamado ao poder (NEVES; MACHADO, 1999, p. 239-247).

Em 1857 um novo gabinete foi formado, com a presidência de Pedro Araújo Lima, o marquês de Olinda. Os gabinetes de Abaeté e Ângelo Muniz Ferraz reforçaram a polarização dos conservadores e liberais. Nas eleições de 1860, os liberais elegeram deputados importantes no Rio de Janeiro, como Teófilo Otoni, Francisco Otaviano e Saldanha Marinho. Em 1861, Ferraz pediu demissão e
Caxias foi chamado, em uma tentativa de conter a presença liberal. Em 1862, Zacarias de Góes, chefe oposicionista, foi chamado para presidir o novo gabinete que durou poucos dias. Foi o início de um período de isolamento dos conservadores ortodoxos, que terminou em 1868 com a queda do terceiro gabinete comando por Zacarias naquele intervalo de tempo (NEVES; MACHADO, 1999, p. 249-253).

Com a queda do gabinete de 3 de agosto e a ascensão dos conservadores em 16 de julho de 1868, teria início o que Sérgio Buarque de Holanda (2008, p. 14) chamou de "a onda que vai derrubar a instituição monárquica”. Embora o Império ainda fosse sobreviver por pouco mais de duas décadas, a troca de ministérios daquele ano e os desdobramentos, indicariam um novo contexto. Nos dias seguintes a 16 de julho, o Conselho de Estado foi convocado. Em 19 de julho, um decreto foi publicado com a dissolução da Câmara dos Deputados. "A gravidade dos sucessos que acabavam de sacudir o país, tomando aparências de golpe de Estado, fazia-os matéria de todas as conversações e era motivo de críticas mordazes à Monarquia e ao Monarca" (HOLANDA, 2008, p. 14).

A figura pública de Zacarias de Góes e Vasconcelos ocupou papel de destaque naquela cena política. Sua longa trajetória incluiu a participação no processo de construção nacional no Brasil, tendo em vista seu envolvimento nas discussões e disputas políticas e partidárias que decorreram no período. Nasceu em 5 de novembro de 1815, em Valença, na Bahia. Há controvérsia sobre sua origem: biógrafos postulam que seus descendentes eram os primeiros portugueses a chegar à Bahia $\mathrm{e}$ que seu pai havia enriquecido com a extração e o comércio de madeira; Albino Pereira dos Santos, contemporâneo e adversário de Zacarias de Góes, afirmou que este era de uma família pobre e filho ilegítimo. Em 1837, concluiu o bacharelado em Direito, em Olinda. Tornou-se professor daquela instituição. Ingressou no partido conservador por intermédio de Francisco Gonçalves Martins, que viria a ser o visconde de são Lourenço e ocupou cadeira no legislativo da Bahia. Nos anos 1840, presidiu as capitanias do Piauí e Sergipe. Na década 
de 1850, ingressou na Câmara dos Deputados, o que deu início à atuação em nível nacional. Faleceu em 28 de dezembro de 1877, no Rio de Janeiro. Era senador, conselheiro, com participação em quatro ministérios e presidente do Conselho de Ministros em três ocasiões (OLIVEIRA, 2002, p. 10).

Machado de Assis, que cobriu as sessões do Senado na década de 1860 , registrou suas nuances na crônica "O Velho Senado", publicada originalmente na Revista Brasileira, em 1898.

Zacarias fazia reviver o debate pelo sarcasmo e pela presteza e vigor dos golpes. Tinha palavra cortante, fina e rápida, com uns efeitos de sons guturais, que a tornavam mais penetrante e irritante. Quando ele se erguia, era quase certo que faria deitar sangue a alguém. (ASSIS, 1994).

Sentava-se à esquerda da mesa, próximo de Nabuco. Quando se aproximava de alguém "era-lhe lhano e simples, amigo e confiado" (ASSIS, 1994). As pessoas que frequentavam sua casa falavam sobre a sua postura polida entre seus livros e de como era um gosto poder ouvi-lo.

Os quatro discursos aqui citados e analisados estão publicados no livro organizado por Cecilia Helena de Salles Oliveira, na Coleção Formadores do Brasil, da editora 34. Foram proferidos no Senado, três deles nos meses de junho e julho, de 1868, dois deles anteriores à crise ministerial, um terceiro após a queda do gabinete em 1868 e, o último discurso, realizado em junho de 1869.

\section{Os discursos de Zacarias: embates partidários, o Senado, o poder moderador e crise ministerial de 1868}

Em 30 de junho de 1868, no discurso proferido por ocasião do voto de Graça, Zacarias reclamava dos insultos a ele remetidos diariamente através das colunas de jornal escritas pelo senador por Minas Gerais, Firmino Rodrigues Silva. O jornal que publicava os debates do Senado, havia dito que Zacarias "ameaçara o Senado", afirmação que se amparava nas notas taquigráficas antes de serem corrigidas pelo orador, como era de costume e direito dos membros de ambas as câmaras. No seu discurso, Zacarias considerou tais acontecimentos como um escândalo.

[...] antes da correção, não é lícito a ninguém, e menos ao redator da folha que tem com a casa um contrato, dizer, para incomodar o ministro (e dizer mal, porque a verdade não abonava a sua asserção), que foi verificar nas notas taquigráficas que a proposição saíra da boca do orador um pouco diferente daquilo que apareceu publicado no discurso. Isso é de certo um escândalo.

Tratava-se do jornal Correio Mercantil, fundado por Francisco Muniz Barreto e Francisco Otaviano de Almeida Rosa em 1836. Deixou de ser editado em novembro de 1868. Zacarias ressaltou: "[...] nunca houve, não há, nem haverá entre o Ministério e o Partido Conservador aconchego algum". A intenção era estabelecer a distância com os conservadores, em um contexto de críticas e disputas políticas. Naquela circunstância, Zacarias concordou e elogiou o senador por São Paulo, Pimenta Bueno, depois marquês de São Vicente, que na tribuna havia afirmado não haver nenhum acordo entre o ministério e o seu partido, uma vez que as circunstâncias eram pouco favoráveis à subida dos conservadores ao poder. Tais circunstâncias se referiam a uma câmara que teria de ser dissolvida, a mudança completa das presidências das províncias que teria de ser feita, além dos chefes de polícia. Em suma, seria necessária uma profunda transformação na ordem política.

Zacarias contrariava José Maria da Silva Paranhos, senador por Mato Grosso. Paranhos mencionara que o presidente do Conselho havia considerado extinta a missão do Partido Conservador. Zacarias afirmava que a circunstância era desfavorável à subida ao poder pelos conservadores e que levantar o fato de que poderia afetar os negócios públicos não era condenálos ao ostracismo. Quando Cotegipe, político conservador e diplomata protestou e disse que a opinião de Paranhos era individual a ele, Zacarias comentou sobre as divergências entre os chefes do Partido Conservador, que, em assuntos graves, 
poderia ser interpretado como falta de unidade. A divergência sobre a ocasião de subir ao poder era um desencontro grave dentro do partido

[...] é necessário que o Partido Conservador, resignando-se, espere a vez de governar, e tenha confiança no seu futuro, na força de seus princípios; mas encostar-se ao partido que ora dirige os destinos do Império, ou àqueles que desse partido separaram-se por motivos que eu talvez averigue em tempo, é sacrificarse, é manifestar ao país que em si não tem recursos para subir; seria afagar os dissidentes entrar com eles em aliança, e logo depois, quando aparecesse ou estivesse próxima a vitória, dizer-lhes "ou nós ou vós".

Zacarias afirmava que os dissidentes liberais eram tão liberais como aqueles que apoiavam o governo. Após a formação da Liga, que havia reunido conservadores e liberais, e depois havia tomado o nome de Progressista, havia se dado uma dissidência. Os históricos eram os liberais que não concordavam com aquele ministério: "[...] $\mathrm{em}$ ideias, em programa, em doutrina, não há diferença alguma".

Zacarias contribuiu para a configuração da Liga Progressista, articulação política que reunia políticos moderados do Partido Conservador e membros do Partido Liberal, com inspiração na Conciliação dos anos 1850; entretanto, com predomínio dos liberais. $\mathrm{Na}$ ocasião, os conservadores Zacarias e Nabuco tentavam isolar os conservadores "emperrados" que giravam em torno do eixo saquarema fluminense. A articulação conseguiu derrubar o gabinete de Caxias em 1862. Foram seis gabinetes liberais ou progressistas que se sucederam até 1866, ocasião em que Zacarias (à frente do Partido Progressista) se articulou e reassumiu o controle do Conselho de Ministros, onde permaneceu até 1868, com a intervenção do imperador (SALLES, 2009, p. 59).

Teófilo Otoni, liberal histórico e senador por Minas Gerais nomeado em 1864, não apoiou a fala do presidente do Conselho. A pauta de Zacarias era tornar evidente a não existência de antagonismo entre os liberais que apoiavam o gabinete e os dissidentes. Foi mencionada pelo presidente do Conselho a fala de Francisco Otaviano, senador pelo Rio de Janeiro nomeado em 1867, que havia proposto uma renovação no Ministério, algo que Zacarias chama de "inocular no ministério sangue novo". Tal fala havia sido reproduzida nos jornais, o que Otaviano imputava à malícia de Zacarias de Góes: "Eu disse que v. exc. tivesse a necessária abnegação para sacrificar-se". Ficou claro para o presidente do Conselho, que a ideia do senador Otaviano era a retirada do gabinete por ele dirigido. O mesmo senador havia feito a menção ao papel do Senado como a diretriz da política do país, o que para Zacarias colocava em questão a saúde política da nação. Zacarias afirmou que o seu ministério tinha conseguido "a passagem de todos os meios de governo", ainda que a maioria fosse de partido contrário à situação. Utilizava metáforas: "esta flor estragou todo o seu ramalhete", referindo-se às atribuições do Senado para influir na política, fazendo ou desfazendo gabinetes, conforme teria evidenciado o senador Otaviano.

Nos idos de 1850, quando membro do corpo legislativo, Zacarias relembrou a unidade dos conservadores, disciplinados, sem discordâncias com os chefes. Na ocasião, analisava as modificações que o partido havia sofrido, por exemplo, com os debates entre São Vicente, que afirmava não ser ocasião própria para subirem ao poder, e Cotegipe, que defendia o oposto, a possibilidade de subida ao poder. "[...] o Partido Conservador, embora com maioria aqui, não pode atrapalhar o governo", reiterava Zacarias. O período referido por Zacarias é o da Conciliação, um dos mais prósperos do império, unindo-se com a atuação de Irineu Evangelista de Sousa, o barão de Mauá, importante empresário da época. Além dos recursos liberados pelo fim do tráfico de escravos, o período coincide com a expansão da lavoura cafeeira pelo Vale do Paraíba (SALLES, 2009, p. 50).

Quando o senador pelo Mato Grosso, José Maria da Silva Paranhos, acusou o gabinete de traçar um círculo de ferro em torno de si, Zacarias afirmou que em face das nomeações de conselheiros de Estado e demais atos que não denotavam exclusivismo, era possível observar que tal círculo 
de ferro inexistia; assim, a referida declaração não poderia partir daquele político. Ressaltou o papel dos conservadores no governo, como conselheiros de Estado e, inclusive, a incumbência da guerra para generais conservadores. "Se o ministério não nomeia conservador algum, é exclusivista; se nomeia um conservador leal, este é logo progressista!", afirmou Zacarias, realizando crítica incisiva ao pronunciamento de Paranhos, que acusava o gabinete de ser o mais exclusivista que havia existido: "Exclusivista um gabinete que chamou o nobre senador para o Conselho de Estado, e que tantas provas há dado de não olhar para os partidos quando se trata de certas nomeações". Na ocasião, o presidente se referia à nomeação do marquês de Caxias, um conservador moderado, a exemplo de Paranhos, que o sugeriu para o comando das tropas no Paraguai.

O senador pelo Mato Grosso, Paranhos, havia trazido a questão da existência dos partidos. Ressaltava a falta de características divergentes entre os partidos, as linhas divisórias estavam apagadas. Francisco Otaviano considerou um equívoco, pois havia dois partidos, o Liberal e o Conservador. Zacarias ressaltou que, para haver partidos, não era necessário somente reunir pessoas, mas "[...] que esses homens tenham certas ideias e as sustentem". Zacarias de Góes e Vasconcelos definia e diferenciava os partidos

Quando, Sr. Presidente, no Brasil o liberalismo perturbava a tranquilidade pública, o Partido Conservador defendia o seu princípio de ordem com toda a energia; porém, desde que o Partido Liberal renunciou a esses excessos, modificou-se o princípio do Partido Conservador, sem perder de todo a sua feição característica. O princípio do Partido Progressista é a liberdade, não sem ordem; o do Partido Conservador é a ordem, não sem liberdade. O que caracteriza os partidos é a preeminência do elemento de cada um deles; do lado dos nobres senadores o elemento que prepondera é a ordem, que não exclui a liberdade. O que querem os liberais? $E$ a liberdade, mas não a liberdade sem a ordem.
Sobre os banquetes realizados com objetivos políticos, a posição do presidente do conselho era de antipatia. Zacarias considerava improdutivos os gastos com banquetes, jantares entre políticos, que segundo ele, eram locais onde nem sempre a lealdade era predominante. Concluía seu discurso repensando a questão sobre estar extinta a missão do Partido Conservador e reiterava que afirmar que a missão do Partido Liberal não estava concluída, não era dar ponto final à atuação conservadora. Como oposição os conservadores tinham um importante papel, que os liberais desempenhariam em situação semelhante: "A tarefa dos dois partidos dura tanto quanto a sociedade", afirmava Zacarias naquele discurso.

No discurso proferido em 3 de julho de 1868, Zacarias iniciou sua fala mencionando o papel do visconde de Itaboraí (Joaquim José Rodrigues Torres) no esclarecimento sobre a influência do Senado na política do país, que teria vindo em tempo "de salvar a Constituição da tortura por que alguns conservadores a queriam fazer passar". O que disse Itaboraí e que defendeu Zacarias, é que o papel do Senado na proposição - discussão e votação dos projetos que deveriam ser convertidos em lei - era de liberdade tão ampla quanto da câmara temporária. Entretanto, no tocante a dirigir bilhetes à Coroa e conformar a derrubada de ministérios, ou seja, manobras políticas diretas, não deveriam ser atribuições do Senado e sim da câmara temporária.

Em 17 de julho de 1868, Zacarias acreditava ser do seu dever expor ao Senado a causa e o modo da exoneração do gabinete de 3 de agosto, o qual presidia e ocupava a pasta da fazenda, e o porquê da decorrência de alguns dias entre o pedido e a concessão da demissão.

No dia 11 de julho, um sábado, o imperador havia solicitado ao ministério posição sobre alguns pontos: primeiramente sobre a escolha de Francisco de Paula Silveira Lobato como senador por Minas Gerais; depois sobre Francisco Salles Torres Homem, também como nome indicado ao Senado pelo Rio Grande do Norte; posteriormente pediu para que fosse feita uma reflexão acerca da eleição do Amazonas, no que se referia a escolher ou não 
um nome da lista tríplice que havia deixado o cargo de presidente da província há menos de seis meses.

Após a retirada do imperador e de deliberarem sobre o assunto, analisaram que seria necessário pedir a sua exoneração, tendo em vista a escolha para senador pelo Rio Grande do Norte, que para o Ministério não seria acertada e, portanto, não poderia assumir a responsabilidade. No dia 12 de julho, Zacarias encaminhou ao imperador uma carta, em conformidade com os colegas de Ministério. Na carta, pedia uma hora para conversar com a majestade. No mesmo dia, o imperador lhe concedeu horário, às 14 horas, momento em que estava em São Cristóvão; e, após recusar a demissão e discutir os motivos, Pedro II pediu que Zacarias buscasse entendimento com os demais membros do Ministério.

Zacarias, então, convidou os colegas para uma reunião em sua casa, naquela noite. A decisão permanecia unânime, diante da escolha do senador pelo Rio Grande do Norte, deixariam o poder. Após a reunião, Zacarias escreveu bilhete ao imperador, $\mathrm{o}$ qual foi respondido com a indicação de uma nova reunião para a tarde do dia 13 de julho. Era ocasião do aniversário da princesa Leopoldina. Os ministros compareceram à reunião e o imperador falou com cada um deles, dos quais ouviu a mesma declaração já concedida por Zacarias. Não concedeu à Zacarias a demissão e pediu para meditar até o dia seguinte. No dia seguinte, Zacarias foi ao São Cristóvão; então, o imperador concedeu a demissão do ministério e pediu que indicasse um sucessor para organizar o novo gabinete, tarefa que Zacarias recusou. Após, Pedro II pediu que Zacarias chamasse ao Paço o visconde de Itaboraí. No dia 16 de julho, Zacarias referendou o decreto que nomeou o visconde Itaboraí chefe do Conselho de Ministros, político que havia elogiado em discurso anterior.

De acordo com Oliveira (2002, p. 13), para a queda do gabinete Zacarias em 1868, duas justificativas foram indicadas:

Uma delas seria a incompatibilidade criada pelo próprio ministério liberal ao indicar Caxias, um político conservador, para o comando das operações militares na Guerra do Paraguai. A outra estaria no impasse gerado pela indicação imperial de Francisco de Salles Torres Homem, também um conservador, para ocupar uma das cadeiras no Senado pela província do Rio Grande do Norte.

Sales Torres Homem, nome que o gabinete comandado por Zacarias não quis referendar como senador, havia desempenhado papel importante na queda do gabinete comandado por Zacarias de Góes, em 24 de maio de 1862. Naquela ocasião, Torres Homem tomou a palavra a apresentou uma moção com inúmeras assinaturas. Questionava a legitimidade do governo de seguir com os debates propostos, entre eles o regulamento das promoções na Armada, visto que a oposição havia subido ao poder com a maioria de um voto, sem dissolução da Câmara e novas eleições para consulta aos eleitores. "[...] o primeiro Ministério Zacarias finou-se ainda mais depressa do que o esperavam seus inimigos, e ficará conhecido na história como o Gabinete dos Três Dias" (HOLANDA, 2008, p. 19).

O paranaense Túlio Vargas, em biografia sobre Zacarias, apontou que a queda do gabinete, após a indicação de Salles Torres Homem para presidir a província do Rio Grande do Norte, indicação a qual o gabinete se opôs por não considerar acertada, pode ser entendida como um incidente provocado pelo imperador para causar a demissão. No caso, Zacarias atribuiu à atitude do imperador, um tom de censura. O autor citou uma nota escrita pelo imperador à margem de um livro de Joaquim Nabuco, na qual ficou posto que o pretexto foi construído. $\mathrm{Na}$ anotação feita pelo imperador, ele menciona não ter cedido a respeito da escolha do Senador devido ao seu desejo, de terminar com honra e proveito às relações externas, a guerra contra o Paraguai. D. Pedro estaria certo de não conseguir prolongar a conciliação entre Caxias e Zacarias e necessitava harmonizar os fatos militares e políticos. Dessa forma, a escolha senatorial teria sido um incidente arquitetado para trazer os conservadores novamente ao poder. "O ministério liberal não podia continuar com a permanência de Caxias à testa do Exército" (VARGAS, 2007, p. 110-101). 
Cecília Helena de Salles Oliveira ressaltou que os biógrafos de Zacarias apontaram como característica central para o fim de seu gabinete, as atribuições do poder moderador, causas de contenda entre o imperador e o presidente do Conselho de Ministros. Após a demissão de Zacarias, os conservadores voltaram ao poder, com Itaboraí nomeado Presidente do Conselho. "Mas as repercussões do episódio foram muito mais graves, motivando a organização não só de um novo partido liberal como das agremiações republicanas" (OLIVEIRA, 2002. p. 13).

Para Raymundo Faoro (2012, p. 505), a destituição do gabinete Zacarias em julho de 1868 expôs o Império ao impulso liberal:

Desse ano de 1868 se projetará a ruína do Império, não, como se afirma sempre, pelo golpe de Estado que arrebatou o posto a um gabinete com maioria na Câmara dos deputados - fato com muitos precedentes -, mas pela ruptura imprudente do quebra-mar construído pela mais fina arte monárquica, sem que a Coroa, insensível à violência da tempestade, nada ceda para conjurar o desastre.

Após tal episódio, Zacarias se notabilizou por fazer oposição aos ministérios conservadores a partir do Senado. O porquê da mudança partidária efetuada por Zacarias, indo do campo conservador ao liberal, assim como as opções feitas quando chefe de gabinete são lacunas a respeito do estadista. Com análise de seus discursos, é perceptível a complexidade da época em que viveu (OLIVEIRA, 2002, p. 13).

Em sessão no senado de 26 de junho de 1869, Zacarias deu ênfase ao que acreditava tratar-se do ódio de Saião Lobato, senador pelo Rio de Janeiro, ao Partido Liberal e seu programa, que deixava de lado os debates sobre a Fala do Trono para fazer oposição. O senador criticou Saião Lobato em duas questões. Primeiramente, o senador pelo Rio de Janeiro teria afirmado que os liberais elaboraram o programa sem uma verdadeira adesão dos membros, e depois, disseminavam a ideia de uma ascensão imediata dos liberais em todas as regiões do país. Nabuco de Araújo já tinha contestado a asserção e Zacarias reforçava a falta de vitalidade do ministério: "[...] o que nas províncias consta, e que consta por toda a parte é que o gabinete como está não pode prosseguir; que há o que quer que seja em presença da unanimidade da Câmara, unanimidade que não é um apoio, mas um perigo".

A oposição ao gabinete era forte. Aliás, uma característica que determinou a personalidade de Zacarias após a queda do gabinete em 1868 foi o seu papel de oposicionista. Uma oposição ferrenha que o senador passou a desempenhar da câmara vitalícia ao governo comandado pelo partido conservador. Em 1870 foi nomeado para o Conselho de Estado, posição que recusou. Túlio Vargas, em sua biografia, heroicizou o personagem, atribuindo sua recusa ao Conselho de Estado como uma prova de caráter. A recusa causaria uma onda de críticas a Zacarias, como o motivo de que desmerecia a Coroa. Ele se justificou pelos jornais, ocasião em que relembrou sua tese defendida em Olinda, de que a monarquia constitucional representativa era a melhor forma de governo para o Brasil, que os ministros de Estado respondem pelos atos do poder moderador, visto que a prerrogativa era do imperador. Parecia-lhe que o cargo oferecido era um meio de aplainar dificuldades nas Câmaras. Criticou o Conselho de Estado: mais um joguete do Governo, do que útil para a administração (VARGAS, 2007, p. 114-117).

O talento de Zacarias para a oposição foi evidenciado na obra de Taunay, contemporâneo do personagem. Taunay nos diz que a posição de Zacarias no Senado era de críticas e intervenções fortes, apesar de aquela ser a casa onde o debate era mais ameno, não prosseguia dessa maneira o conselheiro, que sem hesitar fazia suas críticas incisivas e questionava as atitudes de todos. No Senado, os debates mais fortes não eram comuns. Taunay ressaltou a sutileza que predominava naquele parlamento. "Se havia semideuses em política, eram os senadores do tempo da monarquia". (p. 25). Entretanto, Zacarias de Góes era um caso à parte. $\mathrm{O}$ senador não colocava limites em matéria de realizar aos colegas as mais duras críticas. Era capaz de interromper seu discurso em momentos de auge devido à conversa dos colegas. As brigas 
com Rio Branco e, principalmente, com Cotegipe eram constantes (TAUNAY, 1923, p. 25-28).

A responsabilidade ministerial nos atos do poder moderador era uma tese fundamental da teoria de Zacarias de Góes, que marcou, inclusive, sua transição do partido conservador ao liberal, quando publicou a primeira versão do opúsculo " $\mathrm{Da}$ natureza e limites do poder moderador", em 1860. A obra, reeditada em 1862, é considerada uma versão liberal da teoria e prática do poder moderador: “[...] entendido como referência para o estudo do poder moderador e para a compreensão da estrutura e funcionamento do Estado imperial, como se fosse a síntese dos princípios elaborados pelos liberais ao longo de todo o período monárquico" (OLIVEIRA, 2002, p. 15). Zacarias observou que Benjamin Constant, ao analisar a Constituição inglesa, percebeu que

[...] no acervo de atribuições da realeza, há um grupo que pode figurar à parte; grupo que constituiu o que se chama prerrogativa da Coroa entendeu que essas atribuições podiam constituir um poder separado do Executivo ou ministerial, que ele chamou poder real, e que a nossa Constituição denominou poder Moderador.

Enfatizava que na Inglaterra não existia a distinção entre poder real e ministerial; o rei e a rainha tem como responsáveis, em quaisquer que sejam as ações, os ministros. A declaração de guerra foi escrita por Constant como atribuição do poder real, pois a Coroa seria o órgão do Estado responsável para com o estrangeiro. Se a guerra fosse injusta ou justa, de qualquer modo a responsabilidade seria dos ministros. O fim seria conservar a inviolabilidade real. Assim, seguindo a lógica de Constant, os liberais compreendiam o poder moderador. Quando a decisão da Coroa utilizando a prerrogativa do poder moderador não for assentida pelo ministério, deveriam dar ao conhecimento da Coroa a não concordância.

Suposto isso, temos o poder Moderador pertencendo à Coroa, como querem os conservadores, o poder Executivo nas mãos dos ministros, e a responsabilidade dos ministros em todos os atos da realeza, tanto em uma como em outra ordem de atribuições, satisfazendo a todas as necessidades de um governo livre.

No caso da escolha do ministro para o Rio Grande do Norte, o que se fez foi não aceitar a responsabilidade e, para isso, deixaram de ser ministros. O poder moderador deveria existir naqueles termos, sem responsabilidade alguma ao imperador. "Não é o Partido Liberal que atacou a monarquia, é o Conservador".

Para Zacarias, o ministro que se dizia obrigado a referendar todos os atos do poder moderador, comprometia o sistema representativo. Utilizava de metáfora:

E para que as revoluções se evitem, é preciso pôr sal na cabeça do peixe. O saléa responsabilidade; até hoje as combinações políticas ainda não descobriram outra. $\mathrm{Na}$ Inglaterra, o sal com que se consegue o verdadeiro governo parlamentar é a responsabilidade dos ministros; tem-se a ela efetuado muitas vezes, não obstante a maior proteção aos reis.

O caráter inviolável do monarca deveria ser garantido pelos responsáveis por intermediar as opiniões da sociedade, imprensa e Câmara, para que não atingissem a figura do imperador. Tendo em vista que o rei não estava livre de cometer erros, como todo ser humano, a responsabilidade ministerial o isentaria que tais erros pudessem prejudicar o governo e a coletividade (OLIVEIRA, 2002, p. 33).

\section{Palavras finais}

O conteúdo dos discursos envolve os embates entre os grupos políticos. Como chefe do gabinete de ministros, Zacarias utilizou o senado para defender seu governo dos ataques conservadores. Após sua queda, utilizou o púlpito do Senado para explicar os motivos do fim de seu gabinete, bem como demonstrar que seguia sua teoria política da responsabilidade ministerial. Como opositor ao governo conservador que 
assumiu após o 1868, reforçou a discussão sobre as atribuições do poder moderador e a importância da responsabilidade dos ministros para que a figura do imperador se mantivesse inviolável.

No Brasil imperial, após as demissões dos gabinetes, sucedia-se a dissolução da Câmara dos Deputados. Para um regime presidencialista seria proporcional a um golpe de Estado, no governo imperial era uma forma de consultar a opinião pública sobre manter ou não um governo. A constituição de 1824 admitia em caso de exceção. Para Holanda (2008, p. 118): "Seja como for, é de supor que seu uso seguido e indiscriminado poderia ameaçar a própria segurança do sistema e é o que sucederá mais tarde, quando a exceção se transformar em regra”.

José Murilo de Carvalho analisa o período posterior à crise ministerial de 1868 como um processo de radicalização política, que se estendeu ao ano 1870, quando foi fundado o Partido Republicano. O ministério de Zacarias que iniciou em 3 de agosto foi turbulento. A inclusão da questão servil na Fala do Trono de 1867 e o pedido de demissão de Caxias, conservador, que comandava as operações na guerra do Paraguai, foram pontos de ebulição durante o ministério. Quando levado ao Conselho de Estado, o problema sobre quem demitir, se Caxias ou o gabinete Zacarias, o impasse persistiu, até julho de 1868 (CARVALHO, 2007).

Angela Alonso compreende que a cisão na elite política imperial surgiu quando se colocou em pauta o futuro da monarquia e da escravidão. A maior parte dos liberais e uma ala moderada do Partido Conservador eram favoráveis a uma modernização, lenta e gradual, da política e da economia “[...] no sentido da abolição da escravidão, da laicização do Estado e da democratização das instituições políticas, de modo a garantir a representação das minorias" (ALONSO, 2009, p. 89). Entre os conservadores "emperrados", pairava o medo de que a hierarquia e a ordem política tradicional fosse destruída; portanto, eram oposição. Na virada da década de 1860 para 1870, ocorreu o embate entre tais grupos, exacerbam-se as críticas ao poder moderador feitas pelos liberais, e por outro lado, os conservadores moderados enfrentavam os "emperrados" quando começaram "uma reforma modernizadora". Assim iniciou o contexto de crise nos dois partidos políticos e na ordem que sustentava o império ao longo do tempo. Logo, nasceu o Partido Republicano.

O papel desempenhado pelo estadista Zacarias de Góes e Vasconcelos no decorrer da década de 1860, chefiando gabinetes ministeriais, liderando os progressistas que ascendiam ao poder e buscavam estabelecer-se, protagonizando a crise ministerial de 1868 , foi significativo para compreender os rumos da monarquia no Brasil, assim como a emergência de novos grupos políticos em busca de alteração do status quo imperial, como os novos liberais, os radicais que se tornam clube radical e, posteriormente, republicano, originando o que Alonso (2002) chamou de liberais republicanos, assim como os federalistas científicos e positivistas abolicionistas.

\section{Referências}

ALONSO, Angela. Ideias em movimento: a geração 1870 na crise do Brasil Império. São Paulo: Paz e Terra, 2002.

ALONSO, Angela. A apropriação de ideias no Segundo Reinado. In: GRINBERG, Keila; SALLES, Ricardo (Org.). O Brasil Imperial. Vol. III (18701889). Rio de Janeiro: Civilização Brasileira, 2009. p. 1-30.

ASSIS, Machado de. Obra completa. Rio de Janeiro: Nova Aguilar, 1994. v. II.

CARVALHO, José Murilo de. Liberalismo, radicalismo e republicanismo nos anos sessenta do século dezenove. Centre for Brazilian Studies: University of Oxford, CBS, 2007.

CARVALHO, José Murilo de. A vida política. In: CARVALHO, José Murilo de (Coord.). A construção nacional, 1830-1889. Rio de Janeiro: Objetiva, 2012. p. 83-129.

\section{CARVALHO, José Murilo. A construção da ordem:} a elite política imperial. Teatro de sombras: a 
política imperial. 8. ed. Rio de Janeiro: Civilização Brasileira, 2013.

FAORO, Raymundo. Os donos do poder: formação do patronato político brasileiro. 5. ed. São Paulo: Globo, 2012.

HOLANDA, Sérgio Buarque de. O Brasil monárquico: do Império à República. 8. ed. Rio de Janeiro: Bertrand Brasil, 2008. t. 2, v. 7.

MATTOS, Ilmar Rohllof de. O tempo saquarema. 6. ed. São Paulo: Hucitec, 2011.

NEVES, Lúcia Maria Bastos Pereira; MACHADO, Humberto F. O Império do Brasil. Rio de Janeiro: Nova Fronteira, 1999.

OLIVEIRA, Cecilia Helena de Salles. Da natureza e limites do poder moderador e a memória do conselheiro Zacarias de Góis e Vasconcelos. In: VASCONCELOS, Zacarias de Góis. Zacarias de Góis e Vasconcelos. Organização e introdução de
Cecilia Helena de Salles Oliveira. São Paulo: Ed. 34, 2002. p. 9-58.

SALLES, Ricardo. As águas do Niágara. 1871: a crise da escravidão e o ocaso saquarema. In: GRINBERG, Keila; SALLES, Ricardo (Org.). O Brasil Imperial. Vol. III (1870-1889). Rio de Janeiro: Civilização Brasileira, 2009. p. 39-82.

TAUNAY, Visconde de. Reminiscências. 2. ed. São Paulo: Companhia Melhoramentos, 1923.

TORRES, João Camilo de Oliveira. A democracia coroada. Rio de Janeiro: Livraria José Olympio, 1957.

VARGAS, Túlio. O Conselheiro Zacarias (18151877). 2. ed. rev. e atual. Curitiba: Juruá, 2007.

VASCONCELOS, Zacarias de Góis e. Zacarias de Góis e Vasconcelos. Organização e introdução de Cecilia Helena de Salles Oliveira. São Paulo: Ed. 34, 2002. 